\title{
The Effect of Project-Based Learning and Problem- Based Learning in the Order of Contextual Learning in Microbiology Lectures on the High Order Thinking Skills of Biology Students in FMIPA UNIMED
}

\author{
Hafidatul Husna \\ Biology Department \\ MAN 3 Langkat \\ Sumatera Utara \\ Indonesia \\ hafidatulhusna25@gmail.com
}

\author{
Hasruddin \\ Biology Department \\ Postgraduate Program of Universitas \\ Negeri Medan \\ Medan, Indonesia \\ hasruddin@unimed.ac.id
}

\author{
Tumiur Gultom \\ Biology Department \\ Postgraduate Program of Universitas \\ Negeri Medan \\ Medan, Indonesia \\ tumiur_gultom@unimed.ac.id
}

\begin{abstract}
This study aimed to determine the effect of the application of project-based learning and problem-based learning to the students' High Order Thinking Skills in the fifth semester of biology education undergraduate students in FMIPA UNIMED. This study used a quasi-experimental method with one dependent variable and a study sample of 3 (three) classes determined by random class. Regular class $\mathrm{C}$ got treatment for the application of project-based learning, Extension class A got the treatment of application of problem-based learning, Extension class B (control) got direct learning treatment. The research instrument was a list of description questions to test students' high-level thinking skills. Data analysis techniques used covariate analysis (ANACOVA) at a significant level of $\alpha=0.05$ with SPSS 23 for Windows. The results showed that there was a significant effect among project-based learning $(88.89 \pm 2,592)$, problem-based learning $(85.74 \pm 2,115)$ and direct instruction learning $(84.45 \pm 2,154)$ to high order thinking skills with a value of $F=24,150, P=0,000$. The results of this study stated that the application of project-based learning can improve students' high order thinking skills.
\end{abstract}

Keywords - High Order Thinking Skills; Microbiology; Project based learning; Problem based learning.

\section{BACKGROUND}

Higher education is one level of education that can answer future challenges. In addition, universities must also be able to create high-quality human resources and have a character that is reflected in students' skills in mastering information technology and high-level thinking skills.

One of the problems facing the Indonesian education world is the weak of learning process. The dominant role of the lecturer as a source of knowledge, where so far lecturers give more lectures and exercises to work on problems quickly without giving a deep understanding of the concept. Students are only considered as a place to be filled by knowledge by lecturers, another obstacle is the student achievement evaluation system is more often based on tests that are testing the ability of low-level cognitive.
This causes students to be less trained to develop their reasoning power and apply concepts that have been learned in real life, so that students' higher-order thinking skills cannot develop properly. The low level of student thinking is indicated by the low student learning outcomes. Nuh (2013) states that teachers tend to deliver curriculum content that does not foster students' creativity, so that it cannot bring up high reasoning power for students.

Paul and Elder (2004) state that to be able to improve and develop the learning process it is necessary to create higherorder thinking skills. Quality of life depends on the ability to think at a high level.

The ability of lecturers to manage lessons greatly affects the success of students in this case students in mastering the lesson. Therefore, lecturers must be able to choose the right learning model to develop cognitive, affective, and psychomotor abilities of students. Lecturers as planners, cannot be separated from the task of designing and revising their learning. Davis (2013) states that teachers must consider what material is taught, how best to teach it, and how to ensure that students will learn what is taught.

Learning biology, especially microbiology as part of science, requires a comprehensive high-level understanding to be able to understand it. Prince and Felder (2006) state that science learning has been deductive, lecturers conveying concepts in the form of lectures, developing derivative models, giving examples and practice questions, asking students to work according to the examples given. The final step is to test student understanding in the form of tests. Opportunities given to students to ask about the concepts they want to know are less noticed, so students are not able to develop the concepts learned. According to Herawan (2007), in the process of learning biology, especially microbiology, students not only listen, record and memorize information conveyed by lecturers, but there are opportunities to manipulate and process information. 
From the description above it is clear that for mastery of Microbiology to be successful, students must first be able to master the concepts in learning. Joyce (2009) states that a student is said to have understood a concept if he is able to explain a definition in his own words according to the characteristics / traits that are essential, able to make / mention examples and non-examples, and be able to describe his thoughts or solve problems.

To realize a high level of effectiveness of the behavior of educators and students, one of them is by using project-based and problem-based contextual teaching and learning.

According to Sani (2013), project-based learning supports the achievement of microbiological learning goals, considering that project-based learning is a comprehensive learning process involving students conducting collaborative investigations. Based on the results of Pilang's research (2017) that the high-level thinking ability of students who are taught with a project-based learning model is higher than without project-based learning.

Kunandar (2008) states that Problem Based Learning (PBL) is learning that uses real world problems as a context for students to learn about critical thinking and problem solving skills. Problem based learning (Problem based learning) is one of the innovative learning models that gives active learning conditions to students in real world conditions (Yamin, 2012).

\section{MATERIALS AND METHODS}

\section{A. Research Design}

Data analysis techniques used in this study were descriptive analysis techniques and inferential analysis. Descriptive analysis techniques used to describe data from the study include the mean, median, mode, standard deviation variants, minimum values and maximum values. The data was then presented in the form of a frequency distribution table using the Sturges reference in the form of a Histogram.

\section{B. Samples}

The population in this research were all undergraduate Biology students which were totaling 7 classes and sum of 180 students, at the Faculty of Mathematics and Natural Sciences, Universitas Negeri Medan in Microbiology subject. The sample in this research were only 3 classes which were selected by cluster random sampling.

\section{Instruments}

Inferential analysis techniques were used to test hypotheses. Before testing the hypothesis, the first test was performed on the data collected, namely by testing the normality carried out to determine whether the data we find are normally distributed, normality of data was needed to determine the testing of data to be investigated, namely at the beginning and end of learning. Manually, the normal variable criteria was if 1 count was equal to or greater than the value of 1 table (with an error rate of 0.05). The formula used for the
Normality test was Kalmogorov - Smirnov using SPSS 23 for windows. Homogeneity test was shown to find out whether the two distributions in the experimental and control class groups have the same variation or not. Homogeneity test was performed using the Levens Test on the SPSS 23 for windows program.

\section{RESULTS AND DISCUSSION}

\section{A. Results}

The results of the applying of project based learning and problem based learning as an experimental class, as well as direct instruction as a control class for the initial skill (pretest) and the final skill (posttest) of higher level thinking can be seen in TABLE 1.

TABLE 1. DESCRIPTIVE ANALYSIS OF PRETEST AND POSTTEST ON STUDENT'S HIGH ORDER THINKING SKILLS

\begin{tabular}{ccccc}
\hline $\begin{array}{c}\text { Learning } \\
\text { Model }\end{array}$ & $\begin{array}{c}\text { Minimum } \\
\text { Value }\end{array}$ & $\begin{array}{c}\text { Maximum } \\
\text { Value }\end{array}$ & Mean & $\begin{array}{c}\text { Standard } \\
\text { Deviation }\end{array}$ \\
\hline $\begin{array}{c}\text { PjBL } \\
\text { Pretest }\end{array}$ & 44 & 67 & 54.30 & 6,044 \\
\hline $\begin{array}{c}\text { PBL } \\
\text { Pretest }\end{array}$ & 41 & 61 & 48.30 & 5,431 \\
\hline $\begin{array}{c}\text { DI } \\
\left(\begin{array}{l}\text { Control) } \\
\text { Pretest }\end{array}\right.\end{array}$ & 41 & 57 & 47.86 & 4,969 \\
\hline $\begin{array}{c}\text { PjBL } \\
\text { Posttest }\end{array}$ & 84 & 84 & 88.89 & 2,592 \\
\hline $\begin{array}{c}\text { PBL } \\
\text { Postest }\end{array}$ & 82 & 90 & 86,13 & 2,361 \\
\hline $\begin{array}{c}\text { DI } \\
(\text { Control })\end{array}$ & 78 & 88 & 82.09 & 2,154 \\
Posttest & & & & \\
\hline
\end{tabular}

TABLE 1 shown the results of the students' pretest on high order thinking skills in the experimental class I which was taught by the Project Based Learning model with the highest score of 67 and the lowest value of 44, while the average score and standard deviation were 54.30 \pm 6.044. PBL model as the experimental class II results of the pretest shows the highest score of 61 and the lowest score of 41 , while for the average value and standard deviation of $48.30 \pm 5.431$. The direct instruction learning model (direct learning) as the control class shown the highest pretest score of 57 and the lowest score of 41 , while for the average score and standard deviation of $47.86 \pm 4.969$.

From the results of the posttest on the high-level thinking skill test in the Project Based Learning class, the highest score was 94 and the lowest score was 84 with an average and standard deviation of $88.89 \pm 2.592$. In the class of Problem Based Learning model, the highest score was 90 and the lowest score was 82 with an average score and a standard deviation of $86.13 \pm 2.361$. For the control class (Direct Instruction) the results of descriptive analysis obtained the 
highest score of 88 and the lowest score of 78 with an average standard deviation of $82.09 \pm 3.167$.

After the descriptive analysis was performed, then the prerequisite test for the pre-test and post-test of high order thinking abilities was the normality test with KalmogorovSmirnov can be seen in TABLE II.

TABLE II. KOLMOGOROV-SMIRNOV NORMALITY TEST FOR PRETEST AND POSTTEST IN HIGH ORDER THINKING SKILLS

\begin{tabular}{cccc}
\hline $\begin{array}{c}\text { Learning } \\
\text { Models }\end{array}$ & $\begin{array}{c}\text { Statistical } \\
\text { Tests }\end{array}$ & df & Significance \\
\hline PjBL Pretest & 0.089 & 27 & 0.200 \\
\hline PBL Pretest & 0,120 & 23 & 0,200 \\
\hline $\begin{array}{c}\text { DI (Control) } \\
\text { Pretest }\end{array}$ & 0,137 & 22 & 0,200 \\
\hline PjBL Postest & 0.079 & 27 & 0.200 \\
\hline PBL Posttest & 0.131 & 23 & 0.200 \\
\hline $\begin{array}{c}\text { DI (Control) } \\
\text { Post test }\end{array}$ & 0.154 & 22 & 0.190 \\
\hline
\end{tabular}

The data from Table 2 shown the Kalmogrorov-Smirnov normality test of high-level thinking skill in the pretest of the application of the Project Based Learning model as an experimental class I obtained the distribution of normal distribution data with a significant value of $0.200 \quad 0.05$. In experiment II also obtained the distribution of normal distribution data with a significant value of $0.200 \quad 0.05$ as well as the control class with a significant value of 0.200 0.05 .

The data from Table 2 shown results of the post-test of high-level thinking skill from the Kalmogorov-Smirnov normal test data on the application of the Project Based Learning model as an experimental class I obtained the distribution of normal distribution data with a significant value of $0.200 \quad 0.05$. In the experimental class II also obtained data distribution with normal distribution with a significant value of $0.200 \quad 0.05$ and control class with a significant value of 0.1900 .05 . For the homogeneity test with the Leven's Test, a significant value of 0.3320 .05 was obtained, which means that the final test of high order thinking skill had a homogeneous variant.

The data above shown that the class using the Project Based Learning model has a higher average value compared to other classes. To more clearly the effect of project-based learning on students' higher-order thinking skills can be seen in Fig. 1.

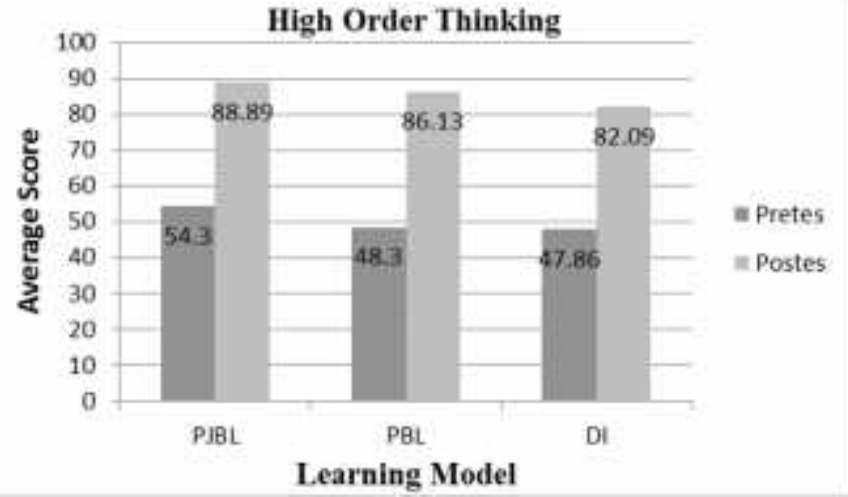

Fig.1. Pretest and Posttest Diagrams Effect of Project-Based Learning on Students' High Order Thinking Skills

\section{B. Discussion}

This means, students' high order thinking skills taught with Project Based Learning (PjBL) were better, because Project Based Learning was one of the learning models that provided opportunities for students to increase learning motivation, learning outcomes, produce a product, focus on solving problems that are relate to student life and bring students to be active in the learning process related to the world of practice. Project Based Learning learning was one of the Student Centered Learning (SCL) that integrates projects in the learning process.

\section{CONCLUSION}

The results of the research data processing show that Project Based Learning (PjBL), Problem Based Learning (PBL), and Direct Instruction Learning (DI) had a significant effect on high order thinking skills of Biology students at the Faculty of Mathematics and Natural Sciences, Universitas Negeri Medan in Microbiology subject.

\section{ACKNOWLEDGMENT}

The author expresses the great gratitude to the supervisors: Dr. Hasruddin, M.Pd. and Dr. Tumiur Gultom, S.P., M.P. who have provided constructive guidance and advice during this research.

\section{REFERENCES}

[1] Davis, B. G. 2013. Perangkat Pembelajaran. Jakarta: Raja Grafindo Persada.

[2] Hasruddin. 2006. Strategi Pembelajaran Kooperatif pada Pembelajaran Biologi. Tabularasa, Jurnal Pendidikan Pascasarjana Unimed. 3(1): 23 29.

[3] Herawan. 2007. Peranan Supervisi Akademik. Jurnal Pendidikan dan Kebudayaan Edisi Khusus II Tahun Ke-13.

[4] Johnson, E.,B. 2007. Contextual Teaching \& Learning, Menjadikan Kegiatan Belajar-Mengajar Mengasyikkan dan Bermakna (diterjahkan oleh Ibnu Setiawan). Bandung: Penerbit MLC.

[5] Joyce, B., Weil, M., \& Calhoun, E. 2009. Models of Teaching. New Jersey. Pearson Education Inc, publishing as Allyn \& Bacon. 
[6] Nuh, M. 2013. Menyambut Kurikulum 2013. Jakarta: Kompas.

[7] Ormrod, J. E. 2009. Education Psychology, Developing Learners. Ohio: Carlisle Comunication, Ltd.

[8] Paul, R and Elder, L. 2004. The Miniature Guide to Critical Thingking. Concepts and Tolls. New Jersey: Prentice-Hall. Inc.

[9] Prince, M, and Felder, R. 2006. The Many Face of Inductive Teaching and Learning. Journal of College Science Teaching, 36 (50), 14-20.
[10] Pilang, M, F. 2017. Pengaruh Model Pembelajaran Berbasis Proyek dalam Tatanan Group Investigation terhadap Berpikir Tingkat Tinggi di USI Pematang Siantar. Jurnal Pendidikan Biologi. 7(1): 42-50.

[11] Sani, A. 2013. Inovasi Pembelajaran. Jakarta: Bumi Aksara. 